\title{
Effectiveness of Using the Meeting Systems in Council Chamber
}

\author{
Kuo-Yu Peng ${ }^{1 *}$ and Hsiu-Li Liao ${ }^{2}$
}

\begin{abstract}
In response to the development of electronic government (e-Government), the government and the legislative assembly have made organizational changes to serve the general public. Local councils have adopted full digital audiovisual meeting systems to address councilors' need for political consultation services. In this study, we explore the actual use of meeting systems based on their main functions. We conducted in-depth interviews with eight councilors using questions designed according to 15 external constructs of the technology acceptance model 3 (TAM 3). The study findings indicated that for councilors who have used the system, their "behavioral intention to use" is mostly correlated with "computer self-efficacy" and "perception of external control" followed by "image." After using the meeting system, the councilors validated the services. The findings reveal that "computer self-efficacy" and "perception of external control" are the two most important subconstructs that positively affect councilors' use of the meeting system, followed by "perceived enjoyment" and "subjective norm." This study provides recommendations based on the interviews on how to accommodate the new technology system, used for reference by manufacturers in marketing and enterprises when implementing the meeting system.
\end{abstract}

JEL classification numbers: C52, H11, M15.

Keywords: electronic meeting system (EMS), interactive video on demand (IVOD), technology acceptance model (TAM).

${ }^{1}$ Ph.D. Program in Business, College of Business, Chung Yuan Christian University, Taoyuan City, Taiwan.

2 Department of Information Management, College of Business, Chung Yuan Christian

University, Taoyuan City, Taiwan.

Article Info: Received: October 14, 2021. Revised: November 5, 2021.

Published online: November 9, 2021. 


\section{Introduction}

Presently, local governments and the legislative assembly have been oriented toward complete e-operation to comply with the policy, and various industries and suppliers have developed a set of digital technology systems in cooperation with the government [1]. Considering the global video conferencing market as an example, the output value exceeded US $\$ 3$ billion in 2019 as the COVID-19 pandemic raised product demand in the industry [2]. This indicates that the system can improve the government administrative efficiency and enterprises execution efficiency [3]. Council is a place of communication under the collegiate system with open and transparent operation processes. When councilors have doubts about the policy addresses of executive departments, they often raise questions orally or in writing in the council chamber. Sometimes when their questions are not answered and explained effectively within the time frame allotted, they may request written or official replies within a certain time frame. This is the system and rule for local councilors seeking information from officials.

This study examines how the adoption of the meeting system has supported councilors in political consultation, thereby attempting to determine how much effectiveness and satisfaction it has brought to the councilors. In the previous research, Qiu [4] highlighted that Facebook is an effective online media tool for political marketing. Politicians can create their personal Facebook profiles and manage them using marketing techniques such as conversational greetings, events, photos of meetings, and response to service cases. The results determine that through Facebook, politicians can obtain political achievements such as reputation, support, and popularity. It is an information system that can be created by individuals at their own convenience.

We will adopt qualitative methods to enhance the practical value of research results. First, we collect information on the main functions for meeting system users through literature discussion on the following topics, namely, live broadcasting, e-voting, and support for political information system, and then, set the research objectives. Later, we explore the technology acceptance model (TAM) through literature discussion. Data and literature will be enriched through feedback gained during indepth interviews. Lastly, we analyze the interview content with reference to the theoretical foundations explored in literature.

With the support of the information system, it is expected that the quality of councilors' political consultation can be improved and the correspondence through official documents can be simplified, so that the meeting systems can be as satisfactory and effective as the business model of Facebook for politicians.

\section{Literature Discussion}

In the following paragraphs, we will discuss relevant literature on the development of meeting systems, live broadcasting of proceedings, e-voting systems, and the TAM, as well as summarize and discuss relevant literature to establish issues to be discussed in this study, and then develop the research framework. 


\subsection{Meeting systems}

The definition of meeting is very broad and includes any activity where individuals come together, whether at the same place at the same time, or in different places at different times [5]. The meeting environment in the form of councils of supervisory bodies in counties and municipalities is known academically as the electronic meeting system (EMS), which is designed to improve the efficiency of group meetings through the application of information technology (IT).

EMS is an IT-based environment that supports group communication that may be geographically or temporally dispersed. The IT environment includes computer hardware and software, audio and video technology, and group data of devices and applications [6]. The difference between the traditional meeting method and the EMS lies in the assistance of IT. Through the control of IT, the way of political consultation adopted by councilors can be effectively presented via the system, and the clarity of questions raised can be effectively enhanced.

According to Nunamaker et al. [5] EMS can provide the following functions: 1 . Effectively provide participants with access to additional information, knowledge, and skills to accomplish their tasks; 2. Provide each participant with the same opportunity to attend the meeting; 3 . Allow the group to choose a method or object from collated results to accomplish the work; 4. Support the development of an organizational database to keep a record of each meeting; 5. Allow participants to work in parallel with data communication.

\subsection{Live broadcasting of proceedings}

Councilors are responsible for supervising the local government. Some councilors are well prepared for inquiries; others often ask questions in the council chamber that are irrelevant to the municipal administration; and some others may only present themselves in the chamber when it is their turn to perform general inquiries of municipal administration. It is important for councilors to improve the satisfaction of their constituencies to convert actual votes [7].

As early as in 2001, the Kaohsiung City Council started with a broadcasting system for proceedings [8]. Presently, 20 county and city councils in Taiwan have successively adopted the interactive video on demand (IVOD) system. Congresses in advanced democracies, such as the US, Germany, and the UK, have live broadcasting of their proceedings. In the US, for example, in 1979, the US cable industry jointly raised US\$500,000 to establish the Cable-Satellite Public Affairs Network (C-SPAN), a nonprofit cable network that broadcasts 24/7 footage of members performing political consultation in the Capitol.

The introduction of the IVOD system for live broadcasting of events helps the public have a better understanding of how public opinion representatives conduct political consultations and gatherings. This transparency also allows people to see clearly which representatives are performing well and which are perfunctory. 


\subsection{E-voting systems}

The ultimate goal of parliamentary discussion is to achieve a result, and voting is a way for councilors to represent their constituents. The main meaning of democracy lies in majority voting, which enables the parliament to reach a final resolution. Different voting methods in practice are also related to the strategic considerations of political parties [9].

The main implication of the role of congressmen on the voting method is that when they are positioned as representatives of the party or constituents, they are willing to follow the party leaders' instructions or the constituents' interests to vote in Congress, and they expect to have the votes recorded by roll call to show that they have voted as directed by the party or to demonstrate their achievements to the constituents. If the role of congressmen is positioned in such a way that they tend to be personal representatives of themselves or of a particular interest group, then they would want to vote in Congress with less interference from others, either on the basis of self-judgment or the position of the particular interest group. They expect that the policy will be adopted by secret ballot to reduce interference from others or criticism from public opinion [10].

Qiu [11] defined e-voting systems in a narrow and a broad sense. The former refers to voting by means of touch screens or buttons, and the latter includes voting by means of marked or punched cards, in addition to the former method. According to Wang [12], voting is the single most effective way to resolve disputes and disagreements in the meeting room. Voting is an important part of the legislative process. Its function is to conclude discussions, resolve disputes, and bring deliberations to a conclusion.

\subsection{Technology acceptance model}

The TAM was first proposed by Davis in 1986. It is used to explain why users accept new technologies and to predict the reasons for acceptance or rejection. Among the constructs of TAM, "perceived usefulness" and "perceived ease of use" are the two most important variables for users' belief; both variables will influence their attitude toward using new technology, and further influence their behavioral intention to use and their actual behavior [13, 14].

Venkatesh and Davis [15] proposed the TAM 2 in 2000, which incorporated the framework of five external variables, namely, "subjective norm" and "image" as in "social influence processes" and "job relevance," "output quality," and "result demonstrability" as in "cognitive instrumental processes." In addition, the moderating variable "experience" was added to moderate the effect of "subjective norms" on "behavioral intention to use" and "perceived usefulness."

Venkatesh and Bala [16] proposed the TAM 3 in 2008 based on the research findings related to the determinants of perceived ease of use in TAM 2. In addition to the social influence processes and cognitive instrumental processes proposed in TAM 2, TAM 3 focuses on extending the two dimensions: "personal anchor" and "system adjustment," which are external variables of perceived ease of use. In terms 
of variables that affect perceived ease of use, personal anchor includes variables such as "computer self-efficacy," "perception of external control," "computer anxiety," and "computer playfulness"; while system adjustment includes variables such as "perceived enjoyment" and "objective usability" as represented in Figure 1.
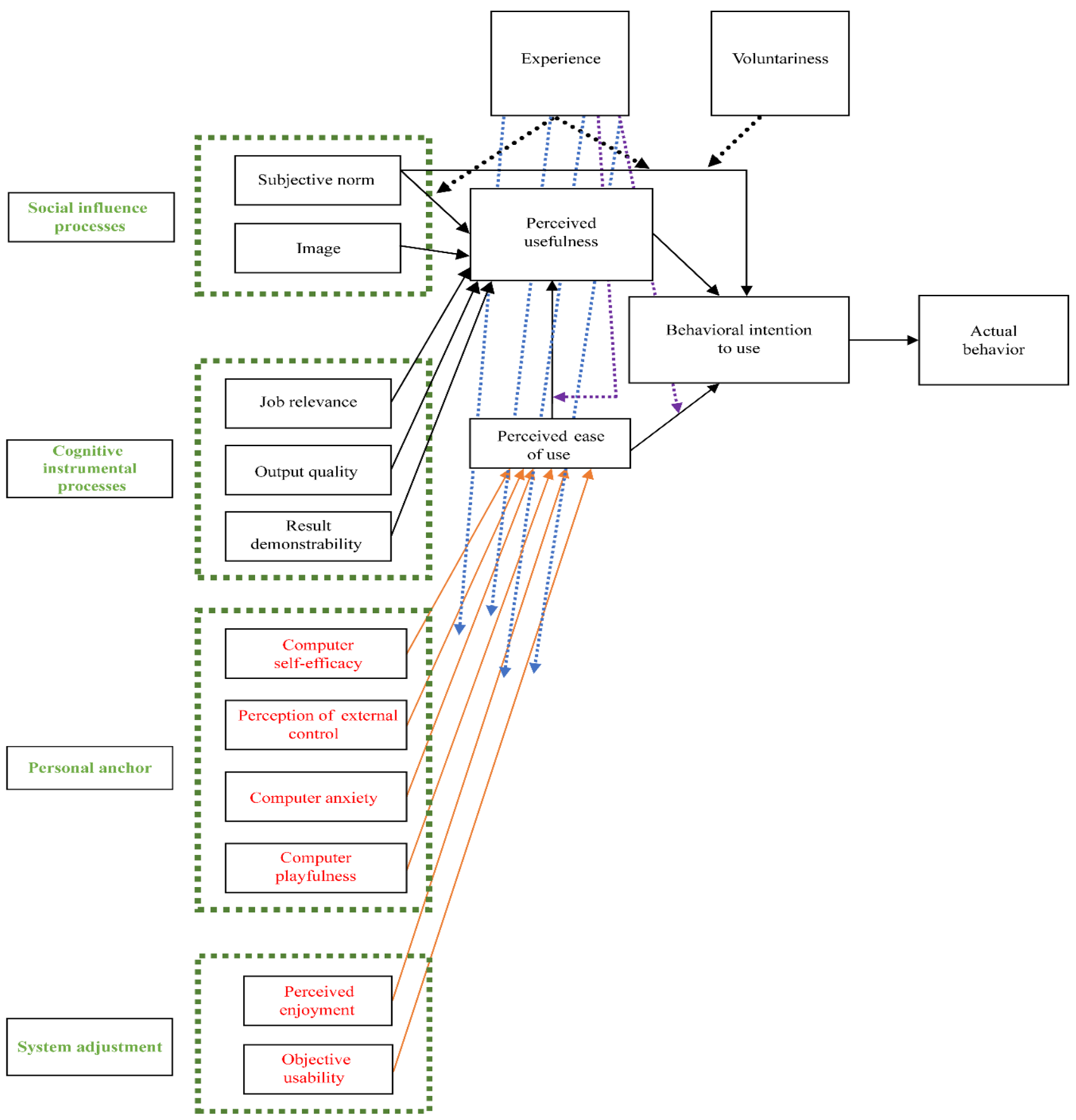

Figure 1: Technology acceptance model 3 (TAM 3) 
The studies on applying the TAM in the fields of science and technology and in industries conducted by domestic scholars are listed in Table 1 .

Table 1: Related literature

\begin{tabular}{|l|l|l|}
\hline Scholars/(years) & \multicolumn{1}{|c|}{ Title } & \multicolumn{1}{|c|}{ Research results } \\
\hline Chang [17] & $\begin{array}{l}\text { The Study of Factors. That } \\
\text { Affect Consumers Adopting } \\
\text { Face Recognition in Mobile } \\
\text { Payment Using TAM }\end{array}$ & $\begin{array}{l}\text { Based on the theory of TAM, factors such } \\
\text { as system quality, system convenience, } \\
\text { social influence, compatibility, perceived } \\
\text { security, perceived ease of use, and } \\
\text { perceived usefulness can effectively } \\
\text { increase consumers' behavioral intention } \\
\text { toward using face recognition in mobile } \\
\text { payment. }\end{array}$ \\
\hline Chang [18] & $\begin{array}{l}\text { A Research on the } \\
\text { Satisfaction of Employees in } \\
\text { the Use of Duty System - } \\
\text { Taking an Enterprise as an } \\
\text { Example }\end{array}$ & $\begin{array}{l}\text { Based on the TAM, it is suggested that } \\
\text { enterprises can strengthen the education } \\
\text { and training on duty system and provide } \\
\text { review and new project operation } \\
\text { instructions to employees. Employees can } \\
\text { make suggestions and offer feedback } \\
\text { during the training process, which can } \\
\text { enhance the applicability of the duty } \\
\text { system, thereby improving the unity of } \\
\text { employees and enterprises. }\end{array}$ \\
\hline Wu [19] & $\begin{array}{l}\text { Exploring Paperless Mobile } \\
\text { Meeting Applications with } \\
\text { TAM }\end{array}$ & $\begin{array}{l}\text { Tuestionnaires based on the TAM. It is } \\
\text { confirmed that the "paperless mobile } \\
\text { meeting applications" developed by this } \\
\text { study can be easily comprehended and } \\
\text { operated by users. Through tablet } \\
\text { computers, we can solve the common } \\
\text { problems of traditional meetings, thereby } \\
\text { improving the efficiency and effectiveness } \\
\text { of meetings. }\end{array}$ \\
\hline
\end{tabular}

From the overview of literature above, it is clear that the TAM can be applied not only to the intangible online world but also to tangible physical products. Whether it is in the field of food, clothing, housing, transportation, entertainment, or medical care, scholars have used the TAM as a theoretical basis to verify the appropriateness of the model and to explain the acceptance of new products by users. 


\section{Research Methodology}

This study is entitled "Effectiveness of Using the Meeting Systems in Council Chamber." As in-depth interview with members involved can better explore the actual operation process, we will use in-depth interviews as the main research method for this study.

\subsection{Research structure}

The TAM 3 suggested by Venkatesh and Bala [16] is utilized as the study's main framework to investigate the effects of councilors' perceived utility and perceived ease of use on their behavioral intention to use the council chamber's meeting system. There are four constructs that affect their perceived usefulness and perceived ease of use, namely, "social influence processes," "cognitive instrumental processes," "personal anchor," and "system adjustment." These four constructs contain a total of 11 variables, namely, subjective norm, image, job relevance, output quality, result demonstrability, computer self-efficacy, perception of external control, computer anxiety, computer playfulness, perceived enjoyment, and objective usability. Another moderating variable "voluntariness" is not considered in the research structure as there is no regulation on whether or not councilors are required to use the technology systems in council. A total of 15 variables are defined in Table 2. 
Table 2: Definition of 15 variables

\begin{tabular}{|c|c|c|}
\hline Variables & Definition & Reference data \\
\hline Experience & $\begin{array}{l}\text { How users feel about an innovative } \\
\text { technology product that they have used }\end{array}$ & $\begin{array}{c}\text { Venkatesh and Davis } \\
{[15]}\end{array}$ \\
\hline Perceived usefulness & $\begin{array}{l}\text { The degree to which users believe that using } \\
\text { a particular technological or information } \\
\text { system would enhance their job performance }\end{array}$ & Davis [14] \\
\hline Perceived ease of use & $\begin{array}{l}\text { The degree to which users believe that using } \\
\text { a particular information system would be free } \\
\text { of effort }\end{array}$ & Davis [14] \\
\hline $\begin{array}{l}\text { Behavioral intention } \\
\text { to use }\end{array}$ & $\begin{array}{l}\text { The degree of willingness whereby users } \\
\text { intend to perform a specified behavior }\end{array}$ & Davis [14] \\
\hline Subjective norm & $\begin{array}{l}\text { The belief that an important person or a group } \\
\text { of people will approve and support a } \\
\text { particular behavior }\end{array}$ & $\begin{array}{l}\text { Venkatesh and Davis } \\
{[15]}\end{array}$ \\
\hline Image & $\begin{array}{l}\text { The degree to which users perceive that using } \\
\text { an innovative product will enhance his/her } \\
\text { status in his/her social system }\end{array}$ & $\begin{array}{l}\text { Venkatesh and Davis } \\
{[15]}\end{array}$ \\
\hline Job relevance & $\begin{array}{l}\text { The degree to which users perceive that using } \\
\text { an innovative system is suitable for the job }\end{array}$ & $\begin{array}{l}\text { Venkatesh and Davis } \\
{[15]}\end{array}$ \\
\hline Output q & $\begin{array}{l}\text { The degree to which users perceive that a } \\
\text { specific behavior can fulfill the current job } \\
\text { task }\end{array}$ & $\begin{array}{c}\text { Venkatesh and Davis } \\
{[15]}\end{array}$ \\
\hline $\begin{array}{c}\text { Result } \\
\text { demonstrability }\end{array}$ & $\begin{array}{l}\text { The results of an innovative technology can } \\
\text { be obviously and directly felt by the users }\end{array}$ & $\begin{array}{l}\text { Venkatesh and Davis } \\
{[15]}\end{array}$ \\
\hline $\begin{array}{l}\text { Computer self- } \\
\text { efficacy }\end{array}$ & $\begin{array}{l}\text { The degree to which users believe that they } \\
\text { are able to use the computer to perform } \\
\text { specific job tasks }\end{array}$ & $\begin{array}{c}\text { Compeau and Higgins } \\
{[20]}\end{array}$ \\
\hline $\begin{array}{l}\text { Perception of } \\
\text { external control }\end{array}$ & $\begin{array}{l}\text { The degree to which users believe that } \\
\text { organizational and technological resources } \\
\text { support their use of the system }\end{array}$ & Venkatesh and Bala [16] \\
\hline Computer anxiety & $\begin{array}{l}\text { The degree of users' emotional responses, } \\
\text { including apprehension, fear, worry, or } \\
\text { repulsion, when they are using computers }\end{array}$ & Venkatesh and Bala [16] \\
\hline $\begin{array}{l}\text { Computer } \\
\text { playfulness }\end{array}$ & $\begin{array}{l}\text { Users enjoy the process of using the new IT } \\
\text { system }\end{array}$ & Venkatesh and Bala [16] \\
\hline Perceived enjoyment & $\begin{array}{l}\text { Users are satisfied with the intrinsic } \\
\text { enjoyment brought by using the computer and } \\
\text { further engage in the utilization }\end{array}$ & Venkatesh and Bala [16] \\
\hline Objective usability & $\begin{array}{l}\text { A comparison result based on the cumulative } \\
\text { experience in using the technology }\end{array}$ & Venkatesh and Bala [16] \\
\hline
\end{tabular}




\subsection{Introduction to the meeting systems in council chamber}

The functions of the meeting system for councilors are divided into three categories, namely, "e-voting system," "multimedia information box," and "live broadcasting of proceedings," which are briefly described as follows.

\subsubsection{E-voting system}

E-voting is mainly used in the council chamber for councilors to vote electronically on bills or projects proposed by government officials. The function buttons are "Yes," "No," and "Abstain." It is possible to decide whether to vote by name or by secret ballot according to the assembly. The operation interface is shown in Figure 2 .

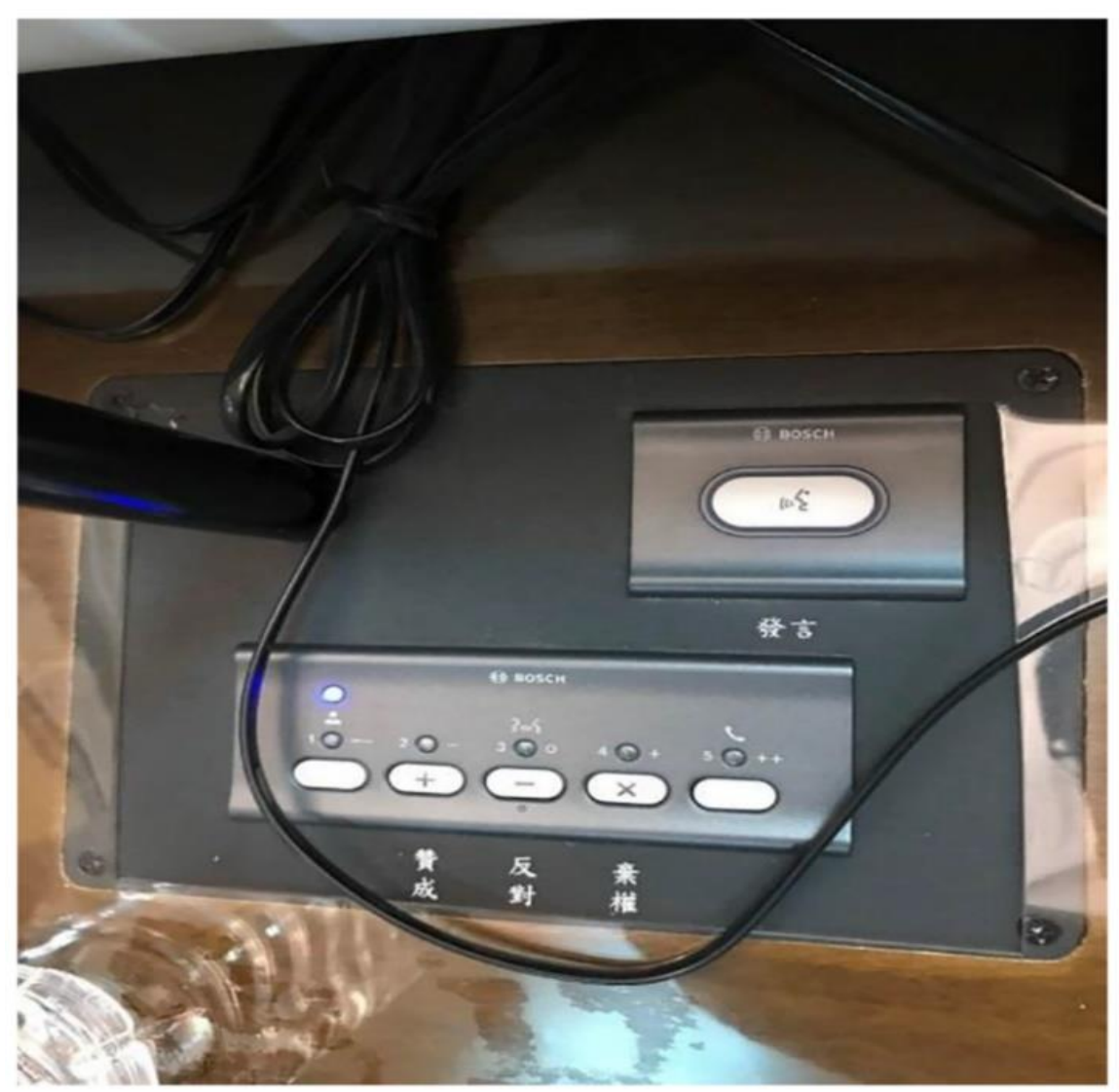

Figure 2: E-voting system

\subsubsection{Multimedia information box}

Some of the transmission media set up in front of individual council tables are "VGA, HIMI, USB, and power connectors," as shown in Figure 3. Councilors can choose whether they want to use computer transmission to display the audiovisual, 
graphical, or briefing documents on a large screen for the officials to prepare for the consultation. The aspect that needs to be discussed is whether electronic inquiry methods are more effective than the traditional written and oral ones.

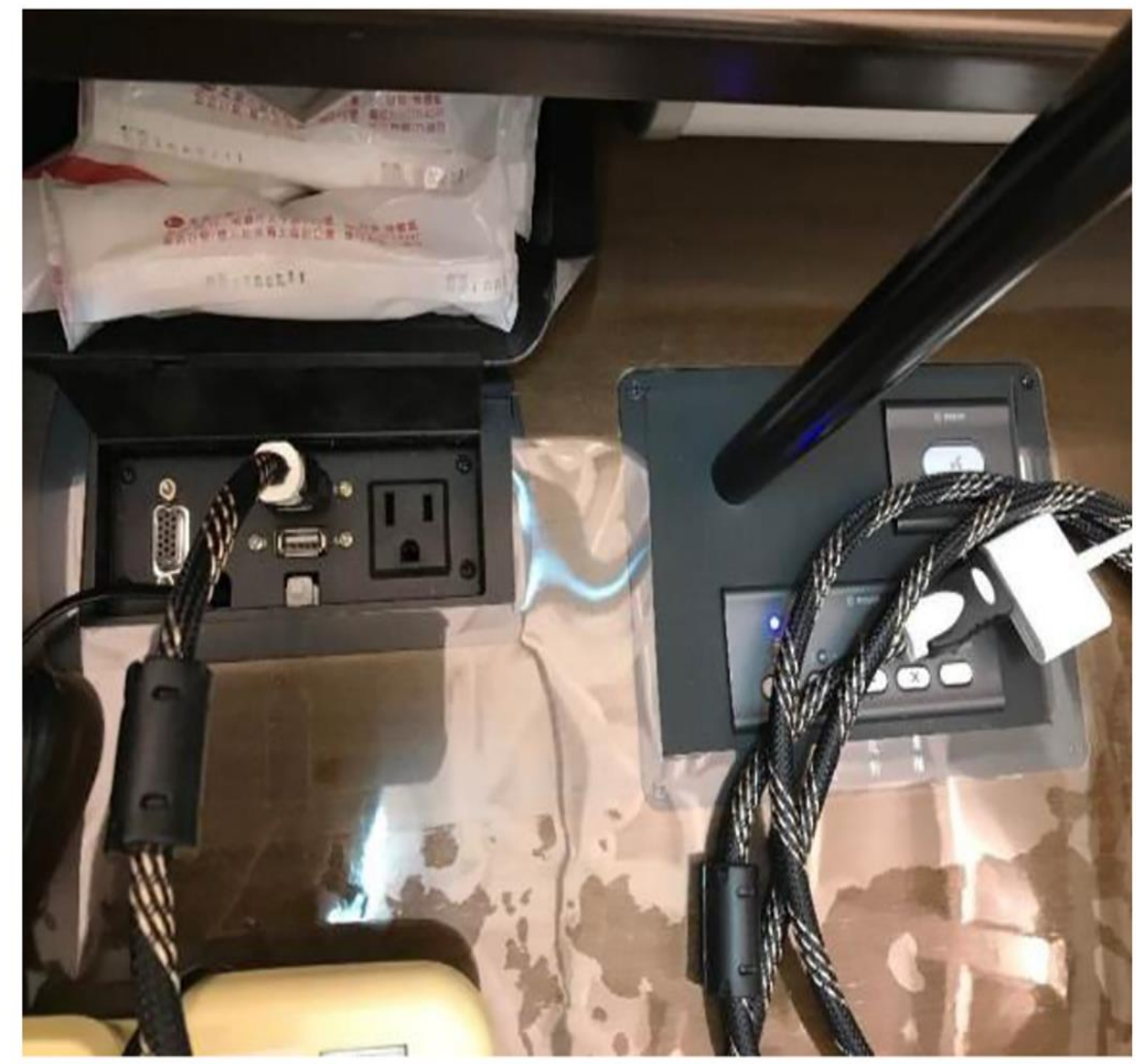

Figure 3: Multimedia information box

\subsubsection{Live broadcasting of proceedings}

The whole meeting process should be videotaped and made public on the Internet using the IVOD system, as shown in Figure 4. Currently, there is no live broadcast with English subtitles in Taiwan. 


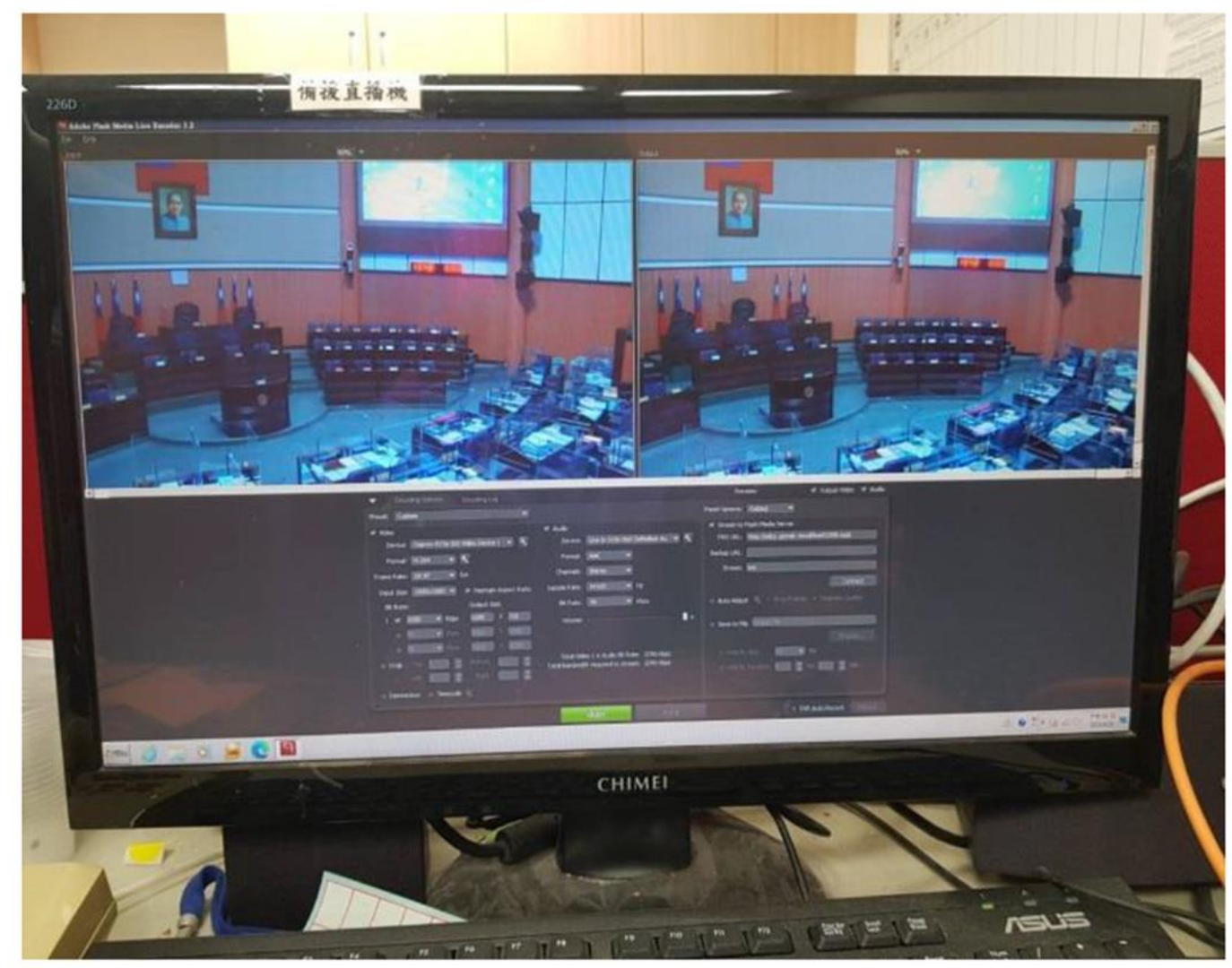

Figure 4: Interactive video on demand (IVOD) system

\subsection{Interview content design}

The outline of the interview in this study is divided into two parts. The first part of the interview was intended to ask questions to the director of the information department that had adopted the meeting system, as well as the secretary general and the director of the deliberation group who actually entered the meeting site and record the meeting process, as described in Table 3. 
Table 3: Interview questions for the secretary general of the council, the director of the information library, and the director of the deliberation group

\begin{tabular}{|c|l|}
\hline Research focus & \multicolumn{1}{c|}{ Main questions } \\
\hline $\begin{array}{c}\text { Adoption and } \\
\text { functionality }\end{array}$ & 1.1 Motivation for adopting the meeting system \\
\hline & 1.2 Purpose of adopting the meeting system \\
\hline & $\begin{array}{l}1.3 \text { What other functions does the meeting system have } \\
\text { besides e-voting, multimedia information box and live } \\
\text { broadcast of proceedings? }\end{array}$ \\
\hline & $\begin{array}{l}\text { 1.4 What is the utilization rate of the meeting system in } \\
\text { council? }\end{array}$ \\
\hline & 1.5 What are your suggestions for the meeting system? \\
\hline
\end{tabular}

The second part of the interview was conducted for the councilors. Before the interview, they were asked whether they had any experience in using IT systems (products), such as computers as a tool for constituent services, in addition to the consultation functions of the meeting system, i.e., "e-voting system, multimedia information box, and live broadcast of proceedings." Later, we used the following outline of interview questions as shown in Table 4 to conduct semi-structured interviews.

Table 4: Interview questions for councilors

\begin{tabular}{|c|c|c|}
\hline Constructs & Subconstructs & Main questions \\
\hline $\begin{array}{l}\text { Moderating } \\
\text { variable }\end{array}$ & Experience & $\begin{array}{l}\text { Do councilors themselves use IT systems (products) } \\
\text { such as computers as a tool for constituent services? }\end{array}$ \\
\hline \multirow[t]{3}{*}{ TAM } & Perceived usefulness & $\begin{array}{l}\text { Do councilors feel that they can improve their } \\
\text { performance (integrity) when they have the support } \\
\text { of the meeting system to conduct inquiries? }\end{array}$ \\
\hline & Perceived ease of use & $\begin{array}{l}\text { Councilors feel that they can easily present their } \\
\text { questions and express them with the help of the } \\
\text { meeting system without consuming much time and } \\
\text { effort. }\end{array}$ \\
\hline & $\begin{array}{l}\text { Behavioral intention } \\
\text { to use }\end{array}$ & $\begin{array}{l}\text { Are councilors willing to use the meeting system } \\
\text { for inquiries? }\end{array}$ \\
\hline \multirow[t]{2}{*}{$\begin{array}{l}\text { Social influence } \\
\text { processes }\end{array}$} & \multirow[t]{2}{*}{ Subjective norm } & $\begin{array}{l}\text { For their constituents, should councilors use the } \\
\text { system to honestly and clearly present issues to } \\
\text { officials? }\end{array}$ \\
\hline & & $\begin{array}{l}\text { The council is not using the e-voting system. If the } \\
\text { President agrees to use the voting system, would the } \\
\text { councilors be willing to use it? What are the reasons } \\
\text { for not wanting to use it? }\end{array}$ \\
\hline
\end{tabular}




\begin{tabular}{|c|c|c|}
\hline & Image & $\begin{array}{l}\text { Councilors believe that using the meeting system } \\
\text { for political consultation will increase their } \\
\text { popularity and they will be in the limelight } \\
\text { (noticed). }\end{array}$ \\
\hline \multirow[t]{3}{*}{$\begin{array}{l}\text { Cognitive } \\
\text { instrumental } \\
\text { processes }\end{array}$} & Job relevance & $\begin{array}{l}\text { Inquiries are related to the use of the system, and } \\
\text { the content of questions can be clearly expressed } \\
\text { through the system. }\end{array}$ \\
\hline & Output quality & $\begin{array}{l}\text { Regarding the functions provided by the meeting } \\
\text { system, I feel that the evaluation is good in terms of } \\
\text { political consultation (the constituents give positive } \\
\text { feedback). }\end{array}$ \\
\hline & Result demonstrability & $\begin{array}{l}\text { Regarding the consultation concerned by the } \\
\text { constituency, with the support of the IT tools } \\
\text { (videos, CD-ROMs) in the council chamber, has the } \\
\text { efficiency of the municipal government improved in } \\
\text { handling councilors' political consultation? Is there } \\
\text { any reduction in the number of visits to the } \\
\text { countryside? }\end{array}$ \\
\hline \multirow[t]{5}{*}{ Personal anchor } & \multirow[t]{2}{*}{$\begin{array}{l}\text { Computer self- } \\
\text { efficacy }\end{array}$} & $\begin{array}{l}\text { Even if the council chamber does not have the } \\
\text { meeting system, councilors will still use portable } \\
\text { computer devices as a tool for political consultation. }\end{array}$ \\
\hline & & $\begin{array}{l}\text { When using the meeting system, they can operate } \\
\text { the system independently without others' } \\
\text { assistance. }\end{array}$ \\
\hline & $\begin{array}{l}\text { Perception of external } \\
\text { control }\end{array}$ & $\begin{array}{l}\text { Do councilors find it easy to use the meeting system } \\
\text { if they have appropriate resources or an assistant to } \\
\text { help them? }\end{array}$ \\
\hline & Computer anxiety & $\begin{array}{l}\text { Are councilors nervous about using the meeting } \\
\text { system or computers? }\end{array}$ \\
\hline & Computer playfulness & $\begin{array}{l}\text { Does it feel comfortable and interesting when using } \\
\text { the meeting system? }\end{array}$ \\
\hline \multirow[t]{2}{*}{$\begin{array}{l}\text { System } \\
\text { adjustment }\end{array}$} & Perceived enjoyment & $\begin{array}{l}\text { The process of using the meeting system is } \\
\text { intrinsically enjoyable, and I will use it more. }\end{array}$ \\
\hline & Objective usability & $\begin{array}{l}\text { How is the acceptance of the system by the } \\
\text { constituents, as councilors spend more time and } \\
\text { gain more experience using the meeting system? } \\
\text { How much can the system help councilors simplify } \\
\text { their political statements on specific (complex) } \\
\text { issues during political consultation? What are the } \\
\text { new features that can be added to the meeting } \\
\text { system? }\end{array}$ \\
\hline
\end{tabular}




\section{Research Results}

Fifteen variables in the TAM 3 were used to examine councilors' willingness to use the meeting system.

The actual interviewees of the study are shown in Table 5. In terms of "experience," all the eight councilors interviewed have used Facebook and Line as communication tools for constituent services. In order to understand the main reasons for councilors to use and not to use the meeting system, this section will explain the four constructs in the TAM 3, namely, "social influence processes," "cognitive instrumental processes," "personal anchor," and "system adjustment" that influence councilors" behavioral intention to use the meeting system and compare their differences.

Table 5: Actual interviewees

\begin{tabular}{|c|c|c|c|c|}
\hline Code & Age & Gender & Education & $\begin{array}{c}\text { Have you used } \\
\text { the meeting } \\
\text { system? }\end{array}$ \\
\hline A & 38 & Male & Master's degree & Yes \\
\hline B & 49 & Male & University & Yes \\
\hline C & 46 & Female & Master's degree & Yes \\
\hline D & 30 & Male & Master's degree & Yes \\
\hline E & 67 & Female & High school & No \\
\hline F & 50 & Female & Master's degree & $\begin{array}{c}\text { Used before, not } \\
\text { now }\end{array}$ \\
\hline G & 40 & Male & Master's degree & Yes \\
\hline H & 63 & Male & Master's degree & No \\
\hline
\end{tabular}

\subsection{Councilors who have used the meeting system}

In the first construct, i.e., "social influence processes": during the interview, five councilors, A, B, C, D, and G, did not mention anything about the subconstruct of "subjective norm," which directly influences their behavioral intention to use the system. Councilor G, in particular, noted that a committee councilor who was reelected to their ninth consecutive term had never used the meeting method previously, but had begun to do so after being influenced by G. We tried to invite the committee councilor for an interview; however, they were unwilling. We learned through their assistant that they had started to prepare briefings for councilors' inquiries. Hence, the findings were confirmed. In terms of "image," only councilor $\mathrm{G}$ felt that it exerted a little influence.

The second construct, i.e., "cognitive instrumental processes" directly influences the five councilors' behavioral intention to use the meeting system. From the perspective of "result demonstrability," we can deduce that inquiries combining briefings and audiovisual equipment could simplify councilors' explanation on 
complex issues and make the discussion in the meeting more focused and not distorted.

The third construct, i.e., "personal anchor" directly influences the five councilors' behavioral intention to use the meeting system, except for "computer playfulness," as the five interviewees did not mention the interesting and comfortable feeling of using the meeting system. Regarding "perception of external control," the councilors' briefings were all produced and edited by their team, and the pressure and hard work were all undertaken by their assistants.

As for the fourth construct, i.e., "system adjustment," the five councilors did not mention the subconstruct of "perceived enjoyment"; in case of "objective usability," only councilor A spoke about the comparison between using the traditional oral method and the meeting system for inquiries.

The relevant subconstructs interviewed for the councilors who have used the meeting system are shown in Table 6.

Table 6: Users' responses to the constructs in the interview

\begin{tabular}{|c|c|c|c|c|c|c|}
\hline Constructs & Subconstructs & $\mathbf{A}$ & $\mathbf{B}$ & $\mathbf{C}$ & D & $\mathbf{G}$ \\
\hline \multirow{2}{*}{$\begin{array}{l}\text { Social influence } \\
\text { processes }\end{array}$} & Subjective norm & & & & & \\
\hline & Image & $\mathrm{V}$ & $\mathrm{V}$ & $\mathrm{V}$ & $\mathrm{V}$ & \\
\hline \multirow{3}{*}{$\begin{array}{l}\text { Cognitive } \\
\text { instrumental } \\
\text { processes }\end{array}$} & Job relevance & V & V & V & V & V \\
\hline & Output quality & $\mathrm{V}$ & $\mathrm{V}$ & $\mathrm{V}$ & $\mathrm{V}$ & $\mathrm{V}$ \\
\hline & Result demonstrability & $\mathrm{V}$ & $\mathrm{V}$ & $\mathrm{V}$ & $\mathrm{V}$ & $\mathrm{V}$ \\
\hline \multirow{4}{*}{ Personal anchor } & Computer self-efficacy & $\mathrm{V}$ & $\mathrm{V}$ & $\mathrm{V}$ & V & $\mathrm{V}$ \\
\hline & $\begin{array}{l}\text { Perception of external } \\
\text { control }\end{array}$ & $\mathrm{V}$ & $\mathrm{V}$ & $\mathrm{V}$ & $\mathrm{V}$ & $\mathrm{V}$ \\
\hline & Computer anxiety & $\mathrm{V}$ & $\mathrm{V}$ & $\mathrm{V}$ & $\mathrm{V}$ & $\mathrm{V}$ \\
\hline & Computer playfulness & & & & & \\
\hline \multirow[t]{2}{*}{ System adjustment } & Perceived enjoyment & & & & & \\
\hline & Objective usability & $\mathrm{V}$ & & & & \\
\hline
\end{tabular}

\subsection{Councilors who have not used the meeting system}

In terms of the subconstructs of "job relevance" and "output quality," councilors E, $\mathrm{F}$, and $\mathrm{H}$ insisted on not using the meeting system despite its convenience. As for "computer self-efficacy," councilor E was one of those who did not know how to make briefings neither did his assistant, as for "perception of external control," 
However, in the interview on "subjective norm," councilor E witnessed that younger councilors were using it well, and said that he also wanted to use it.

However, councilor F had used it previously, but did not want to use it again as he felt uncomfortable in terms of "perceived enjoyment," and he further stated that the meeting system was not as convenient in terms of "perceived ease of use."

In terms of "subjective norm," Councilor $\mathrm{H}$ had no desire to use the meeting system as his clansmen liked him to write calligraphy with brush pen and make largecharacter posters for inquiries, which remained unchanged for several years.

The relevant subconstructs interviewed for the councilors who have not used the meeting system are shown in Table 7.

Table 7: Nonusers' responses to the constructs in the interview

\begin{tabular}{|c|c|c|c|c|}
\hline Constructs & Subconstructs & E & F & H \\
\hline \multirow{3}{*}{ Social influence processes } & Subjective norm & & & V \\
\hline & Image & V & & \\
\hline \multirow{3}{*}{$\begin{array}{c}\text { Cognitive instrumental } \\
\text { processes }\end{array}$} & Job relevance & V & & \\
\hline & Output quality & & & \\
\hline & Result demonstrability & & & \\
\hline \multirow{4}{*}{$\begin{array}{c}\text { Personal anchor } \\
\text { Computer self-efficacy }\end{array}$} & $\mathrm{V}$ & $\mathrm{V}$ & $\mathrm{V}$ \\
\hline & Perception of external control & $\mathrm{V}$ & & \\
\hline & Computer anxiety & & & \\
\hline & Computer playfulness & & & \\
\hline System adjustment & Perceived enjoyment & & $\mathrm{V}$ & \\
\hline & Objective usability & & & \\
\hline
\end{tabular}

Among the eight councilors interviewed, A, B, C, D, and G had "behavioral intention" to use the system; councilor E wanted to use the system, but for reasons of "computer self-efficacy," he did not know how to use computer to make briefings, and because of his "perception of external control," he could not find a suitable assistant who could make briefings. Councilor F stopped using the meeting system due to his nearsightedness and farsightedness, for reasons of "perceived enjoyment," and because of the inconvenience of using remote control to present briefings while looking and holding at the same time, for reasons of "perceived ease of use." Councilor $\mathrm{H}$ did not use it due to the preferences of his clansmen, for reasons of "subjective norm," thereby making it difficult for him to use the system. 


\subsection{The effectiveness of the meeting system brought about by council supervisors}

The feature of the meeting system is to diversify the councilors' political consultation; it has the following three effects: First, it can help councilors handle the content of their political consultation more precisely and carefully. Second, it can help officials avoid the situation of "explicit question with ambiguous answer." Unlike in the past, photos and videos are now on the scene as evidence to prevent officials from providing confusing replies. Third, by making administrative legislation more understandable to the public, it increases the veracity of "knowledge" gained via knowledge seeking.

In summary, most of the responses and suggestions from the interview were positive. The councilors rated the adoption of the meeting system as high for its help in political consultation. They had no special expectations and ideas regarding the improvement of the meeting system at the moment, except that some did not want to use it due to the preferences of clansmen, personal habits in political consultation, or personal health problems. Nevertheless, for those who wanted to use the meeting system, it was difficult to generate perceived usefulness and perceived ease of use toward the system. This topic can be further explored in the future by improving the conditions and environment of use.

\section{Conclusions and Recommendations}

The most important function of the meeting system in council chamber is to provide an information-based system that facilitates the public to "check councilors' inquiries and dynamics." It allows the public and various sectors to quickly access councilors' real-time information and services related to inquiries without going through complex vetting procedures. Moreover, through real-time live broadcasting available to the public, individuals can use hand-held carriers to understand the requirements of administrative legislation during "knowledge" seeking.

This study uses the TAM 3 proposed by Venkatesh as the main research framework to design interview questions and explores the influences of councilors' perceived usefulness and perceived ease of use on their behavioral intention to use the meeting system in the council chamber. It is determined that councilors' "behavioral intention to use" is most related to "computer self-efficacy" and "perception of external control." According to younger councilors, people watching live broadcasting through the IVOD system can improve their reputation. Correspondingly, on simple issues, the inquiries of political consultation can be communicated orally; while complex issues require the support of the meeting system to make the facts presented clear at a glance.

Among the councilors who have not used the meeting system, the first councilor was influenced by "computer self-efficacy," in which he did not know how to use computer, and by "perception of external control," in which he did not have an assistant; the second councilor was influenced by "perceived enjoyment," in which he felt uncomfortable after using the system, and by "perceived ease of use," in 
which the meeting system became less convenient for him; and the third councilor was influenced by "subjective norm," in which he did not use the system because his clansmen preferred his style of political consultation.

Overall, the purpose can be achieved by educating councilors on the operational ease of the meeting system as well as the extent to which it can simplify the explanation on complex issues, thereby enhancing their perceived usefulness and increasing awareness of the system's usage. In this study, all the subconstructs can be used to improve councilors' behavioral intention to use, except for "subjective norms," as through this subconstruct, it is difficult to change councilors' behavioral intention to use and their own political consultation style.

In terms of recommendations, the purpose of using the meeting system in council lies in the fact that it can help officials avoid the situation of "explicit question with ambiguous answer" by precisely processing the content of political consultation, and thus, improve administrative efficiency.

We would like to provide a few recommendations to be used as reference for manufacturers in marketing and for enterprises in introducing the meeting system.

1. Provide education and training for the meeting system, such as operating instructions for manufacturers to improve users' perceived ease of use.

2. For the research on e-voting, it is suggested that the study should be conducted at the level of the Legislative Yuan, and that it is inappropriate to study it in the local councils. The director who serves the local councils considers such a study appropriate for a secret review (defense diplomacy). In addition, the study on the effectiveness of live broadcasting reveals that it is more suitable for "influencers" and "youtubers" and less suitable for improving the reputation of councilors.

3. Furthermore, as suggested by councilors, computers can be placed in front of their council tables, so that for future inquiries they can store data and transmit pictures and videos to the big screen at any time. The operation will be simple and easy to learn. It will make councilors feel it is easy to use, and thus, motivate them to use it.

4. Due to the outbreak of the COVID-19 pandemic in 2019, more and more meetings are conducted online instead of face-to-face, and the meeting systems of various manufacturers and enterprises have also become the center of attention in a short time span. Manufacturers are developing new functions in the software to rapidly popularize the e-meeting system; however, the government and enterprises are not prepared to introduce the system [21]. Hence, suggestions for system improvement as well as its usage experience as expressed in the interview by the council supervisors and councilors in this study can be used as reference for other local councils and enterprises to evaluate and expand the functions when adopting the meeting system in the near future. 


\section{References}

[1] Collins, J. (2020). “Web-based video conferences," RadioGraphics, vol. 40, no. 5, 2020, pp. 1309-1317.

[2] Okereafor, K. and Manny, P. (2020). "Understanding cybersecurity challenges of telecommuting and video conferencing applications in the COVID-19 pandemic," Journal Homepage: http://ijmr. net. in, vol. 8, no. 6, 2020.

[3] Chinatimes.com (2020.05.24) (Topology Research Institute - Video Conferencing Equipment Industry under the Pandemic). https://www.chinatimes.com/newspapers/20200524000148-260204?chdtv.

[4] Qiu, Y. (2013). "A study on the strategies of the Facebook management by politicians: The case of the ninth legislator-at-large seats," Dissertation, Institute of Information Management, Chung Yuan University, 2013, pp. 1-80.

[5] Nunamaker, J. F., Dennis, A. R., Valacich, J. S., Vogel, D. and George, J. F. (1991). "Electronic meeting systems," Communications of the ACM, vol. 34, no. 7, 1991, pp. 40-61.

[6] Dennis, A. R., George, J. F., Jessup, L. M., Nunamaker, J. F. and D. R. Vogel, D. R. (1988). "Information technology to support electronic meetings," MIS Quarterly, 1988, pp. 591-624.

[7] Lin, X. (2006). "A study on the councilor service quality and satisfaction in Taipei county," Master's thesis, Master in Public Administration, National Chengchi University, Month 2006, pp. 1-114.

[8] Gu, Z. and He, S. (2009)."The VIOD system makes our congress more open and transparent," New Century Forum, no. 45, 2009.

[9] Roberts, J. M. and Smith, S. S. (2003). "Procedural contexts, party strategy, and conditional party voting in the US House of Representatives, 19712000.” American Journal of Political Science, vol. 47, no. 2, 2003, pp. 305317.

[10] Isaak, A. C. (1985). "Scope and methods of political science: an introduction to the methodology of political inquiry," Dorsey Press, 1985.

[11] Qiu, C. (2004). "A study of election reform in Taiwan: An observation from e-voting experiences in developed countries," RDEC Bimonthly, vol. 28, no. 4, Month 2004, pp. 25-35.

[12] Wang, B. (1997). "On the procedure and system of the Legislative Yuan in Taiwan," Fu Hsing Kang Academic Journal, no. 62, Month 1997, pp. 97-121.

[13] Davis, F. D. (1985). "A technology acceptance model for empirically testing new end-user information systems: Theory and results," Doctoral dissertation, Massachusetts Institute of Technology, Month 1985.

[14] Davis, F. D., Bagozzi, R. P. and Warshaw, P. R. (1989). "User acceptance of computer technology: A comparison of two theoretical models," Management Science, vol. 35, no. 8, Month 1989, pp. 982-1003.

[15] Venkatesh, V. and Davis, F. D. (2000). "A theoretical extension of the technology acceptance model: Four longitudinal field studies," Management Science, vol. 46, no. 2, 2000, pp. 186-204. 
[16] Venkatesh, V. and Bala, H. (2008). "Technology acceptance model 3 and a research agenda on interventions," Decision Sciences, vol. 39, no. 2, 2008, pp. 273-315.

[17] Chang, H. (2018). "The study of factors that affect consumers adopting face recognition mobile payment using Technology Acceptance Model," Master's dissertation, School of Information, Kainan University, 2018, pp. 1-70.

[18] Chang, Y. P. (2019). "A research on the satisfaction of employees in the use of duty system - taking an enterprise unit as an example," Master's dissertation, College of Computer Science and Information, Chung Hua University, 2019, pp. 1-74.

[19] Wu, P. Y. "Exploring the paperless mobile conferencing applications in Technology Acceptance Model," Master's dissertation, International Program for Interaction Design and Innovation, National Taipei University of Technology, pp. 1-54.

[20] Compeau, D. R. and Higgins, C.A. (1995). "Computer self-efficacy: Development of a measure and initial test," MIS Quarterly, 1995, pp. 189-211.

[21] Gray, L. M., Wong-Wylie, G., Rempel, G. R. and Cook, K. (2020). "Expanding qualitative research interviewing strategies: Zoom video communications," The Qualitative Report, vol. 25, no. 5, 2020, pp. 1292-1301. 